\title{
Perception towards Regulatory Burden on Small and Medium Enterprises Performance: A Case Study in Shashemene Town, West Arsi Zone, Ethiopia
}

\author{
Ofgaha Alemu Dire (MSc) \\ Lecturer, Accounting and Finance Department, Bule Hora University, Ethiopia \\ Email: ofgahaalemudire@gmail.com \\ Wegene Bekele Bekelcha (Msc) \\ Lecturer, Accounting and Finance Department, Bule Hora University, Ethiopia \\ Email: wegenebekele2006@gmail.com
}

Received: January 3, 2020 Accepted: February 21, 2020 Published: March 4, 2020

doi:10.5296/ber.v10i1.16608ＵRL: https://doi.org/10.5296/ber.v10i1.16608

\begin{abstract}
The study focuses on "perception towards regulatory burden on small and medium enterprise performance" in Shashemene town, west Arsi zone, Oromia regional state, Ethiopia. The study adopted a qualitative research approach to address broad objective through answering research questions developed by a researchers. Specifically, this study used questionnaire to collect data from SMEs business owners, managers and employees and in-depth interview conducted. Data was analyzed by using descriptive statistics. The information obtained from a samples of the 140 small and medium enterprise and through face-to-face interview of 10 owners of SMEs business. The respondents were selected using stratified sampling techniques. The result of the study show that small and medium enterprise challenges from different factors as they perceived from the challenges of regulatory burden and identifies mechanisms used to mitigate problems from regulatory burden and how much the regulators have smooth contact with them and to what extent regulators made inspections. Moreover, the result indicated the perception of SMEs businesses towards regulatory burden. As a whole, the study suggests a series of measures should be taken by government policy, makers and regulators for SMEs performance. Researchers' conclude and recommend that government bodies, Small and medium enterprise business owners, managers, employees and policy makers should focus on regulation to reduce regulatory burden on small and medium
\end{abstract}


enterprises.

Keywords: SMEs, Regulators, BERR, Business Development Service

\section{Introduction}

Currently the major development challenge is the promotion of economic growth and reduction of poverty. To alleviate poverty and bring economic development government of different countries under take different development strategies, such as creating an environment that encourages and support small and medium size enterprise (SMEs) sector initiatives and enabling them to operate with a system of good regulations, which is necessary in order to create and sustain an enabling environment for development, with respect to this area. In developing countries, SMEs by virtues of their size, capital investment and their capacity to generate greater employment and have demonstrated a powerful propellant effect for their rapid economic growth. Throughout the world policy makers are turning to small and medium enterprise to drive economic growth and development of the small and medium enterprise are regarded as the primary creators of jobs and economic stability. The vital contribution that small and medium enterprise can make to employments and income generation is recognized in worldwide particularly African countries (Brink, Cant, \& Lightht, 2005).

The Small and medium enterprise sector has also been instrumental in bringing about economic transaction by providing goods and services, which are adequate quality and reasonable priced to a large number of people and by effectively using the skill and talents of large number of people (ILO,2008,PP,56). Similarly, Lara and Simeon, (2009; pp, 1453-1464) founded that SMEs generates substantial employment and economic out-put in many countries. Their share of overall employment tends to be higher in developing countries, which are typically more focused on small and medium enterprise. The sector has potential to provide the ideal environment for enabling entrepreneurs to optimally exercise their talents and to attain their personal and professional goals (MoTI, 1999). The small and medium enterprise sector also seen as an important force to generate employments and more equitable income distribution, activate computation, exploit markets, and enhance productivity and technical change to stimulate economic development.

The Ethiopian government now struggle against poverty through adopting a better development strategy. According to Quartey (2005), SMEs are necessary engines for achieving the national development goals such as economic growth, poverty alleviation, democratization and economic participation, employment creation and industrial base and local production escalation. The role of SMEs as engine of growth, for example by the postwar recovery in Austria and Germany and by the diverging paths of the central European and Baltic countries from those of the common wealth of independent states (Brixiova and Emerta, 2010).

Therefore, this sector is the backbone for development of all developed and developing nation. To take the advantage of this major role countries strive to adopt better regulation, because regulation with which small and medium enterprise operate create a burden either 
directly and indirectly. The relationship between regulation and business is complex, because regulation has also both positive and negative relationship on the performance of business.

Those regulations that influence the performance of business sector requires firms to impose cost that impede startup, investment innovation, employment growth, and ultimately, weaken national economic performance (Nicolette and scarpetta, 2005). Even though no society can exist without state providing some kind of order regulation, excessive regulation on society especially on business entity hinders to achieve their objective or business success. In this regard, British chambers of commerce (2002) state that excessive regulation is an emerging barriers to the survival and growth of the business.

The burden of regulation and SMEs performance insist on policy makers and representatives of all the business sector in all countries to undertake assessment of regulatory burden on SMEs and ensure that the extent that regulation affect Small and medium enterprise. SMEs severely affected directly or indirectly by red tape that may emanate from inappropriate adoption, implementation and adverse administration of regulations. Because they are less proficient in dealing with aspects of regulation that affect their performance mostly they exposed for business failure than larger businesses (Sievers and Vandenberg, 2007).In Ethiopia, the small and medium enterprise and the informal sector are the pre dominant income generating activities.

\section{Statement of the Problem}

Since the late 1960s it has been thought that the target to promote small enterprise has been changed with donors emphasizing on the role of SMEs in encouraging industrialization (sievers and Vandenberg, 2007). As a result, studies showed that in developed countries like, United Kingdom SMEs became the focus of the government, consequently, Even if limited studies are there in Ethiopia but, most studies in other countries showed that SMEs play an important role in the economic development of countries. More specifically past studies indicate that in developing countries of south Asia SMEs constitutes over $97 \%$ and contribute between 40-60\%of the total output to their national economies (Fan, 2005; Kamesam, 2007, Nepal, etal.2005; Shretha.2005, cited in Syedel, al.2008).

In addition, as stated in the World Business Council for Sustainable development (WBCSD)"'in organization for economic co-operation and development (OECD) economies SMEs and micro enterprise account for over $95 \%$ of firms, $60-70 \%$ of employment, $55 \%$ of GDP and generate the lion share of new jobs. In developing countries more than $90 \%$ of all firms outside the agricultural sector are SMEs and micro enterprise is generating a significant portion of GDP.

The SMEs play an important role in the development of the national economy of any country .In Indonesia SMEs have been the main players in domestic economic activities as they account for more than $90 \%$ of all firms and $96.2 \%$ of total work force, especially women and youth .On average the GDP growth share of SMEs was above $2 \%$, where as that of large enterprise was under 2\% (Tambunan, 2011). Ahmed et al (2011) presented about the system approach for the effective adaptation of rapid prototyping for SMEs and they pointed out the 
role of SMEs in the economy for instance in the UK out of the total of $48 \%$ million UK business about $99 \%$ were SMEs while less than $1 \%$ were large corporation.

Well regulated SMEs are particularly important in developing countries like Ethiopia for poverty reduction strategy because they are seedbed for the development of large enterprise and because they absorb agriculturally under employed labor and diversify the source of income for farming families so government should set better regulation and good business environment to scale up the growth and performance of SMEs to take the advantage of economic growth.

Ethiopia is not unique in this regard, considering the degree of unemployment as well as realizing the role of SMEs toward sustainable employment generation. The government has to give due attention in terms of promoting favorable business environment to take advantage of their contribution for economic development. But, burden of administration work and high amount of resource to comply with the regulation are some of the problems of regulation and government look through and assure all the above aspects not to become an obstacle for the success of the business. Many of the traditional problems of SMEs such as lack of financing, low- product, difficulties in exploring technology, constrained managerial capabilities are the regulatory burden that became more acute in a globalized technology driven environment (OECD, 2011).

The regulation and its burden upon business are major topic of public debates among the politician, median, commentators, academic groups and practitioners because the regulatory frame work create and enforce state organization profoundly shapes all economic activities. Therefore before setting policies and regulations Policymakers and regulators themselves should assess regulatory burden that influence the startup, growth and expansion of business enterprise. SMEs and their contribution for the development of the economy, regulation and effects on SMEs performance and growth and the researcher inquiring aiming to enhance understanding and to address the burden of regulation and its problem on SMEs performance and growth. To assure the effect of regulation on business success there should be a serious assessment of those regulation whether they are effective or not. As to the researcher's knowledge regulatory burden assessment taskforce has been organized in Ethiopia, as a result their appears to be lack of sufficient research and empirical evidence on this issue. To fill this gap the study assesses perception towards regulatory burden on the performance of SMEs based on evidence from as perceived by owners, managers, and employers.

\section{Research Questions}

The research questions has been developed as follows

1. Do SMEs consider existing regulations as burden? If so which ones?

2. Which area of regulation creates a major burden on SMEs performance?

3. How do SMEs mitigate problems arising from the burden of regulations?

4. Which aspects of regulation have a major burden on SMEs success?

5. Does the government consult with SMEs prior to regulating to lesson problems related with regulations? 


\section{Objectives of the Study}

The main objective of the study is to assess the perception of small and medium enterprise owners, managers and employees towards the regulatory burden on the SMEs performance particularly in private limited and sole proprietorship business in West Arsi zone, Ethiopia. Specifically, the study

1. Identify the area of regulation that creates major burden on SMEs performance.

2. Know how SMEs mitigate problems that arise from the burden of regulation.

3. determine how regulations became burden for SMEs business success

4. Assess whether government consult with SMEs prior to regulating to lesson problems related to regulation.

\section{Literature Review}

Small and medium enterprise are increasingly seen as playing an important role in the economies of many countries in terms of poverty alleviation, democratization and economic participation, employment creation and industrial base and local production escalation. Thus, governments through the world focus on the development of the SMEs sector to promote economic growth and at the same time regulate this business sector, because regulations shape their activities and outcomes. Even regulation effluence business performance by enabling and motivating small and medium enterprise to achieve their objective but, it also constrain them. As OECD (2004) showed, the notion of SMEs and entrepreneurship development was introduced in to the growth and development landscape as early as the late of 1940's with the introduction of targeted policies (grants, subsidized credits, special tax treatments etc). And the establishment of small business or SMEs support agencies by governments. (E.g. publically founded SMEs agencies were set up in 1948 in Japan, 1953 in USA, 1954 in India, 1966 in Tanzania, and 1976 in Turkey.

SMEs sector carries great hope and great burdens in the evolution of all of the transitional economies. SMEs get serious concern because of its contribution for countries ability to withstand completion in the global economy, to create jobs, and to continue to develop economically. The sustained and healthy growth of this sector is obviously necessary, since it is difficult to imagine rising over all living standard social peace without such a development. For instance, as recently as the 1980s, the ability of the United states to withstand completion in global economy was in question, as a result scholars began the difficult tasks of documenting the crucial role played by SMEs as a driving engine of growth, job creation and competitiveness in global markets and policy makers responded with a supporter emphasis on policies to promote SMEs (Audretsc, 2006).

Further the economic significance of the small business sector in generating income and sustaining employment has been recognized by successive UK governments since the 1960's (Dilani, 2005).Therefore the SMEs evolution and adaptability increase from time to time and government regulated SMEs within the economy, since this regulatory frame work created and enforced by governments profoundly shapes all economic activities including SMEs.

Regulations play an important role in enabling or restricting the progress of businesses 
depending on how well they are prepared and implemented. No one doubts that production and market require regulations in order to operate fairly and competitively for the goods of the society as a whole. As the concern of governments, regulatory practitioners and commentators have developed a corresponding changes that has taken place in prospective to provide foundation for the study of regulation. However the evidence indicated that the regulatory burden is increasing and that there are a number of areas of concern for the SMEs community policy makers need to take Account of areas where the regulatory burden is significant and be careful not to add to the regulatory burden, unless the benefits clearly outweigh costs.

SMEs play significant contribution especially in the transaction of agriculture lead economies to industrial ones furnishing plain opportunity for processing activities which can generate sustainable source of revenue and enhance the development process. SMEs hold up the explanation expansion of systematic productivity capability. They help to observe productive resources at all levels of the economy and add to the formation of flexible economic systems in which small and large firms are interlinked such linkages are very crucial for the attraction of foreign investment. SMEs are the major growing force behind the fastest growing economy of developed countries like china, in terms of contribution to the national GDP, scale of assets, diversification of products, creation of employment and reducing poverty and as a whole increasing the welfare of the society (Ahmed, Javiad \&Said, 2008).

There are a number of factors responsible for the importance of SMEs in developing countries. First, SMEs strengthen an entrepreneurial spirit and put forward flexibility in the economy. Second, SMEs emanates the fastest growing export sub-sector, third, they can support the poverty alleviation endeavors through employment generation process. Above all, SMEs are more efficient in resource allocation as compared to that of a large scale industry from a social point of view and they also provide and facilitate employment opportunity from more number of people as compare to that of large-scale industry. The significant roles of SMEs were indicated by research and statistics from many developed countries, however, effort had remained restricted focusing on large enterprise, and neglecting small and medium enterprises which are the backbone of the economy. SMEs use mainly local resource and those have less foreign exchange requirements will adapting easily to customer requirements. Due to their small and perceived flexible nature of SMEs are expected to be able to with stand adverse economic conditions and survive where many large businesses would collapse (Aryeetet \& Ahene, 2002).

SMEs have been of increasing interest for academics and policy makers in recent years since their role in both developed and developing economies have been established as a being major. This contribution from small and medium size for the overall economic development is currently acknowledged by severs countries. For instance, evidence is available for the major role of SMEs in the growth and development of all leading economies in Asia (United Nations).However, the availability of SMEs to release this economic and social objective depend on the regulatory and policy environment with in which they operate (ILO, 2000 cited in quarterly, 2001).Despite the importance of SMEs businesses in developing countries particularly in Africa face many obstacles. Among those obstacles policy and regulatory 
burden can make a considerable difference to how well the SMEs sector fulfills its potential role in contributing to a healthy economy. In, SMEs are a distinctive foundation of the economy that requires owing attentiveness by the government. Therefore, failure to develop SMEs may slow down the restructuring process of the economy increase the volume of an employment, early retirement and other and discourage investment and other employment creating opportunity. The environment for SMEs is continually, especially in the scenario of globalization and openness' of the economies. Therefore, the course of action for SMEs should be set for long run period keeping in mind to put in a sustainable regulatory environment.

Complex regulatory environment requires more business resource for understanding, handling and complying with the given regulation. Small and medium enterprise find more costly and difficult to cope up about regulation whether they apply and how best to comply with them, particularly those regulations which are complex or badly drafted (OECD 2001).

According Keter (2004), Regulations may have unintended or unforeseen negative consequences, such as causing damage to particular markets or employment and training opportunities. The actions of regulators may further create burdens for business. For example, a regulator's inconsistent application (or interpretation) of regulatory requirements may necessitate a number of changes in the operations of a business in order to achieve compliance, despite the underlying regulatory requirements remaining unchanged. Even where a business does not need to undertake such changes, the uncertainty caused by the inconsistent approach of regulators can, in itself, cause a regulatory burden. The partial enforcement, or non-enforcement, of regulations may also create a regulatory burden by placing businesses complying with the regulations at a competitive disadvantage when compared to non-complying businesses. All these potential burdens can be exacerbated for enterprises doing business across. They are likely to have their compliance costs compounded because of differing or duplicated regulatory requirements, even if those regulations have the same policy objectives

Documents reveals what people do or did what they value. This behavior occurred in a natural setting, so the data has strongly validity. Commercial registration and business licensing proclamation no.686/2010 is released through the Federal Negarit Gazeta and also accessible on website to read and comply with it. It started that any person shall register in commercial register only once even though he carries on different commercial activities in different regions. Moreover, any person who open branch office where his branch office where is situated that any person who open branches office in many places shall inform the registering office where his branch office is situated, the address of branch office and his special identification number of registration by completing appropriate application form and attaching photocopies of his commercial registration certificate and business lenience before commencing operation. Business licensing regulation No.14/1917 stated that any person engaged in a commercial activity whose capital is more than ETB 5000 shall obtain a business license by applying through a relevant bureau in his/her region.

With regarding to registration and licensing Business Development Service (BDS) forum 
prepared a module for SMEs. As the report of this BDS the registration fee needed for small business is low and the total fee shall not exceed ETB 100 and summary registration the fee is ETB 10 (Gagel, 2008).

Further, BDS indicated that total fee and time required for business registration adapted for medium enterprises is a total of ETB 645 within 16 days. Concerning tax proclamation and regulations, taxable business income shall be determined per tax period on the basis of profit and loss account on income statement. which shall be drawn on compliance with Generally Accepted Accounting Standards subject to the provision of this proclamation and the directives issued by the tax authority, but if any amount of tax is not paid by due date, tax payers is obliged to pay interest on such amount for the period from the date the tax is due to the date its paid (Income tax proclamation No.286/2002). Moreover VAT returns and payment of liability amended VAT proclamation No.609/2008 stated, every registered person shall be required to file a VAT return with the authority by appearing in person or through electronic filing or through a third delegated by the authority for each accounting period concerning the conduct of tax authority employees income tax proclamation No.286/2002 stated that each employees of tax authority shall be honest and fair, treating each tax payers with courtesy and respect apply with laws, regulation and ruling to each case on the basis of the objective.

The proclamation under article 48 under sub article 1 stated about recording and keeping i.e. all person who are engaged in a business or a business or who own building held all or in part for rental except for category " $\mathrm{C}$ " tax payers shall keep books and records. That is record of all daily income and expenses related to the business activity and the matter to which they relate and a record of all purchases and sales of goods and service relate to the business activity.

Pertaining to product quality, the enforcement of some Ethiopian standard is made mandatory by the government in view of health, safety, fair trade and related considerations and their enforcement is carried out by Quality standard authority of Ethiopia (QSAE). Ethiopian standard provide industry and users with the frame work for economies of design, greater product and services quality and better production and delivery efficiency. At the same time, Ethiopian standard also promote an improved quality of life by contributing to safety human health and the protection of environment (EBDSN, 2004).

The small and medium enterprises performance relies mostly on perception towards different regulations like complexity of regulations, rate of changes of regulations, volume/number of regulations and inspections of regulations. The researchers is therefore obliged to research on the Perception towards regulatory burden on SMEs. 


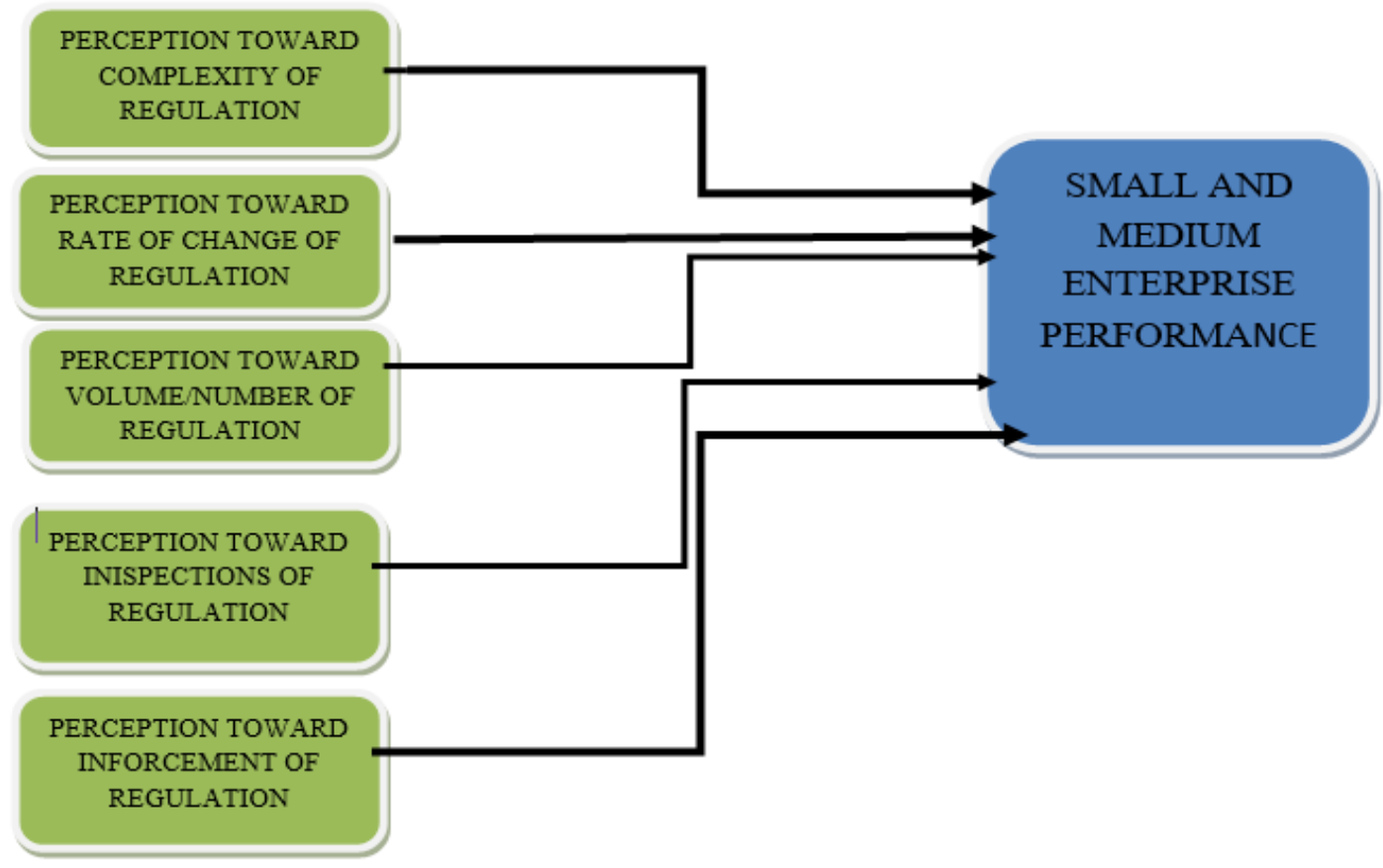

Figure 1. Conceptual Model

Source: Researchers Model from literature, 2017

\section{Research Methodology}

This study was used descriptive research Design to describe state of affairs as it exist at present and quantitative research methods particularly survey methods and qualitative methods particularly in depth interview to assess opinions of SMEs owners or managers towards regulatory burden on performance of small and medium business the researchers used qualitative approach because this approach is concerned with subjective assessments of small and medium enterprise business owner's perceptions towards regulatory burdens.

the sampling frame were the 216 registered SMEs operate in the Shashemene Town particularly private limited companies and sole proprietorship form of business because large numbers of entrepreneurs are involved in such types of legal status. Moreover, survey method were also applied to generalize the population from the sample. Therefore, to draw sample the following procedures were applied i.e. firstly the list of SMEs from the office of trade and industry were assessed and grouped based on their activity by using stratified sampling method to corporate all sectors in the target population. Finally, to draw sample respondents for the questionnaires from the given stratum simple random samplings were used.

Researchers was used stratified sampling techniques because there were different businesses activities exist in the population. Those business activities are manufacturing, constructions, trading hotels and restaurants service and professional service were intend to used simple random sampling from each stratum. Data were collected from head managers of the enterprises, members (owner) entrepreneur and others hired employees of these Small and Medium Enterprises operating in the town. Here, at 95\% confidence level and 5\% margin of 


\section{I) Macrothink}

Business and Economic Research

ISSN 2162-4860

2020, Vol. 10, No. 1

error or significance level; the following formula was used to determine the sample size for finite population.

The following formula developed by Taro (1967) was used for the sample size.

$$
\mathbf{n}=\frac{N}{1+N(\delta)^{2}}
$$

Where, $\mathrm{n}=$ sample size, $\mathrm{N}=$ number of population, $\delta=$ acceptable error

At acceptable error (sample error) $5 \%$

$\mathrm{N}$ - Number population which was 216 MSEs in Shashemene town.

$$
\mathbf{n}=\frac{216}{1+216(0.05)^{2}}=\underline{\underline{140.2597}}
$$

SMEs had included in the study by using random sampling techniques. The formula is used to determine the sample size when the population is believed to be large enough and difficult to study it as a whole.

To determine the proportionate sample size which is taken from each SMEs sector, the following formula will be used.

$$
\text { For example trade sector }=\frac{\text { No.of SMEs in Trade (78) }}{\text { Total No.of SMEs in Shashemene town }(216)} \text { Sample size }(140)=\underline{\underline{50}}
$$

Table 1. Sample size taken from the five business sectors of SMEs in Shashemene town

\begin{tabular}{|l|l|l|}
\hline Business Sectors & $\begin{array}{l}\text { No. of SMEs } \\
\text { in each strata }\end{array}$ & $\begin{array}{l}\text { Proportionate sample } \\
\text { Size of each SMEs }\end{array}$ \\
\hline Trade & 78 & 50 \\
\hline Manufacturing & 14 & 9 \\
\hline Hotels and restaurant service & 68 & 44 \\
\hline Construction & 32 & 21 \\
\hline Professional service & 24 & 16 \\
\hline Total & 216 & 140 \\
\hline
\end{tabular}

\section{Result and Discussion}

To address the research problem using a survey method the researchers used self-administered structured questionnaire. As the main sources of information the respondents of this study were SMEs owners, managers and employees in Shashemene town, west Arsi zone, Ethiopia. 
Table 2. Gender of respondents

\begin{tabular}{|l|l|l|l|}
\hline \multicolumn{2}{|c|}{} & Frequency & Percent \\
\hline \multirow{3}{*}{ Valid } & Male & 112 & 84.8 \\
\cline { 2 - 4 } & Female & 20 & 15.2 \\
\cline { 2 - 4 } & Total & 132 & 100.0 \\
\hline
\end{tabular}

Source: Survey result, 2017

As per the above (table 4.1): The result shows that more of the respondents were show male i.e. which accounts $84.8 \%$ and $15.2 \%$ were females. This indicates that most of the respondents are male. Besides to this the result of interview shows that the majority of the respondents were males according to this study.

Table 3. The main business activity of SMEs business

\begin{tabular}{|l|l|l|l|}
\hline \multicolumn{2}{|c|}{} & Frequency & Percent \\
\hline \multirow{5}{*}{ Valid } & Manufacturing & 19 & 14.4 \\
\cline { 2 - 4 } & Construction & 29 & 22.0 \\
\cline { 2 - 4 } & Trade & 38 & 28.8 \\
\cline { 2 - 4 } & Hotel and restaurants & 27 & 20.5 \\
\cline { 2 - 4 } & Professional service & 15 & 11.4 \\
\cline { 2 - 4 } & Other & 4 & 3.0 \\
\cline { 2 - 4 } & Total & 132 & 100.0 \\
\hline
\end{tabular}

Source: survey result, 2017

As per the table 4.6, the result of the respondents were shows that most of the activities of the enterprises were participated in merchandising inventories (trading activities) that is $28.8 \%$ and $22.0 \%$ of the responses were shows the activities of the construction. Hotels and restaurants, Manufacturing, professional service and other were $20.5 \%, 14.4 \%, 11.3 \%$ and $3.0 \%$ respectively.

The result of the study confirmed that most of the enterprises provided the activities of the trade and constructions. 


\section{Ml Macrothink}

Business and Economic Research ISSN 2162-4860 2020, Vol. 10, No. 1

Table 4. Regulatory burden as an obstacle of SMEs business performance

\begin{tabular}{|c|c|c|c|c|c|c|}
\hline & & $\begin{array}{l}\text { Regulation } \\
\text { are } \\
\text { obstacle } \\
\text { because of } \\
\text { complexity }\end{array}$ & $\begin{array}{l}\text { Regulation } \\
\text { are obstacles } \\
\text { because of } \\
\text { inappropriat } \\
\text { e } \\
\text { enforcement } \\
\end{array}$ & $\begin{array}{l}\text { Regulation } \\
\text { are obstacles } \\
\text { because of } \\
\text { rate of } \\
\text { change is } \\
\text { high } \\
\end{array}$ & $\begin{array}{l}\text { Regulation } \\
\text { are obstacles } \\
\text { because of } \\
\text { volume of } \\
\text { regulation } \\
\text { are high } \\
\end{array}$ & $\begin{array}{l}\text { Regulation are } \\
\text { obstacles because of } \\
\text { there } \\
\text { inappropriate } \\
\text { inspections' }\end{array}$ \\
\hline Strongly & count & 45 & 12 & 14 & 10 & 53 \\
\hline & percent & 34.1 & 9.1 & 10.6 & 7.6 & 40.2 \\
\hline Agree & Count & 36 & 15 & 23 & 28 & 31 \\
\hline & percent & 27.3 & 11.4 & 17.4 & 21.2 & 23.5 \\
\hline Neutral & count & 25 & 26 & 36 & 29 & 14 \\
\hline & percent & 18.9 & 19.7 & 27.3 & 22 & 10.6 \\
\hline Dis agree & Count & 12 & 35 & 27 & 35 & 20 \\
\hline & percent & 9.1 & 26.5 & 20.3 & 26.5 & 15.2 \\
\hline Strongly & Count & 14 & 44 & 32 & 30 & 14 \\
\hline & percent & 10.6 & $\begin{array}{l}33.3 \\
\end{array}$ & 24.2 & 22.7 & 10.6 \\
\hline mean & & 2.35 & 3.63 & 3.3 & 3.35 & 2.32 \\
\hline sd & & 1.32 & 1.23 & 1.3 & 1.254 & 1.406 \\
\hline $\min$ & & 1 & 1 & 1 & 1 & 1 \\
\hline $\max$ & & 5 & 5 & 5 & 5 & 5 \\
\hline total & & 132 & 132 & 132 & 132 & 132 \\
\hline
\end{tabular}

Source: survey result, 2017

According to table 4, Businesses were asked to express their agreement or disagreement with statement of different aspects of regulation. As showed in the above table (4.9) majority of the respondents which is about $53(40.2 \%)$ and 31 (23.5\% of respondents were strongly agreed and agreed with the statement of Regulation are obstacle because of its inappropriate inspections' and about $15.2 \%$ and $10.6 \%$ of respondents disagree and strongly disagree the statements. About $34.1 \%$ and $27.7 \%$ of respondents were also strongly agreed and agree with the statement of regulation are obstacles because of its complexity. The respondents that respond regulation are obstacles because of its inappropriate enforcement and regulation are obstacles because of rate of change is high accounts about $11.4 \%$ and $17.4 \%$ respectively and its mean $(\mathrm{x}=3.63$ and $3.3, \mathrm{~N}=132)$.Regarding to the statement of regulation are obstacles because of volume of regulation are high accounts about $21.2 \%$ of respondents agreed and $26.5 \%$ of respondents disagreed on the statement. Further with regarding to Aspects of regulation, regulations are obstacles because of its complexity and regulations are obstacles because of its inappropriate inspections are the two statements that are strongly agreed and agreed by the majority of respondents. Besides the result of interview also shows that as as majority of the respondents agreed on the statement of regulation are obstacles 
because of its complexity and regulations are obstacles because of its inappropriate inspections.

\section{frquency of regulation regarding tax related regulation like VAT Frequency \\ never ance a year twice a year a more than twice a year $\square$ Total}
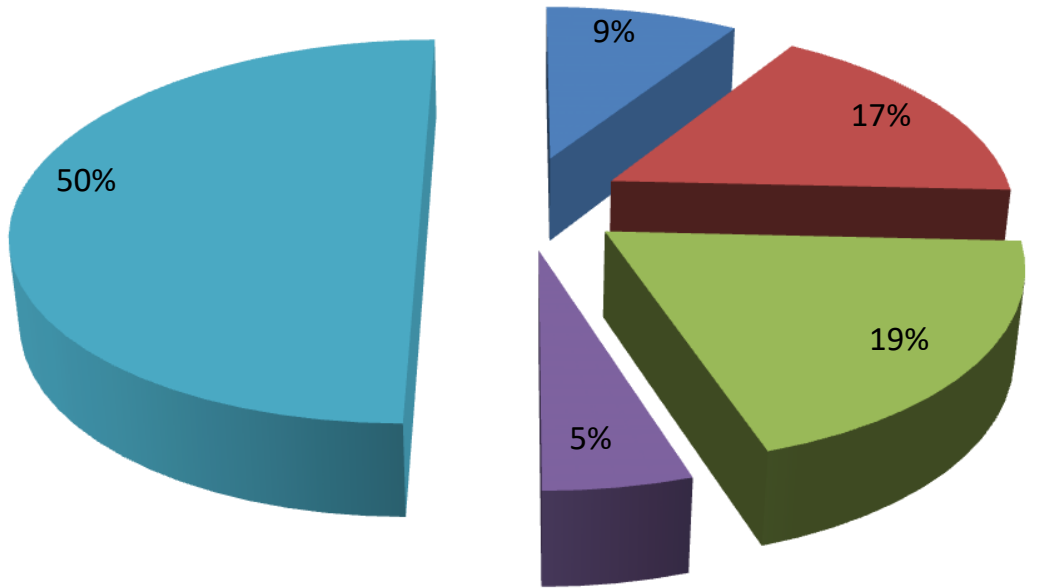

Figure 2. Frequency of regulation regarding Tax related regulation like VAT

Source: survey result, 2017

As showed in the above figure the result identify about $75 \%$ of respondents prepare tax report annually, where as $18.2 \%$ of respondents indicate their firms prepared report 2-3 times in a year and about $6.1 \%$ and $0.8 \%$ of respondents were respond as they made 4-6 times and more than six time in a year respectively. Further the above result showed that the majority of the businesses made their report annually. 


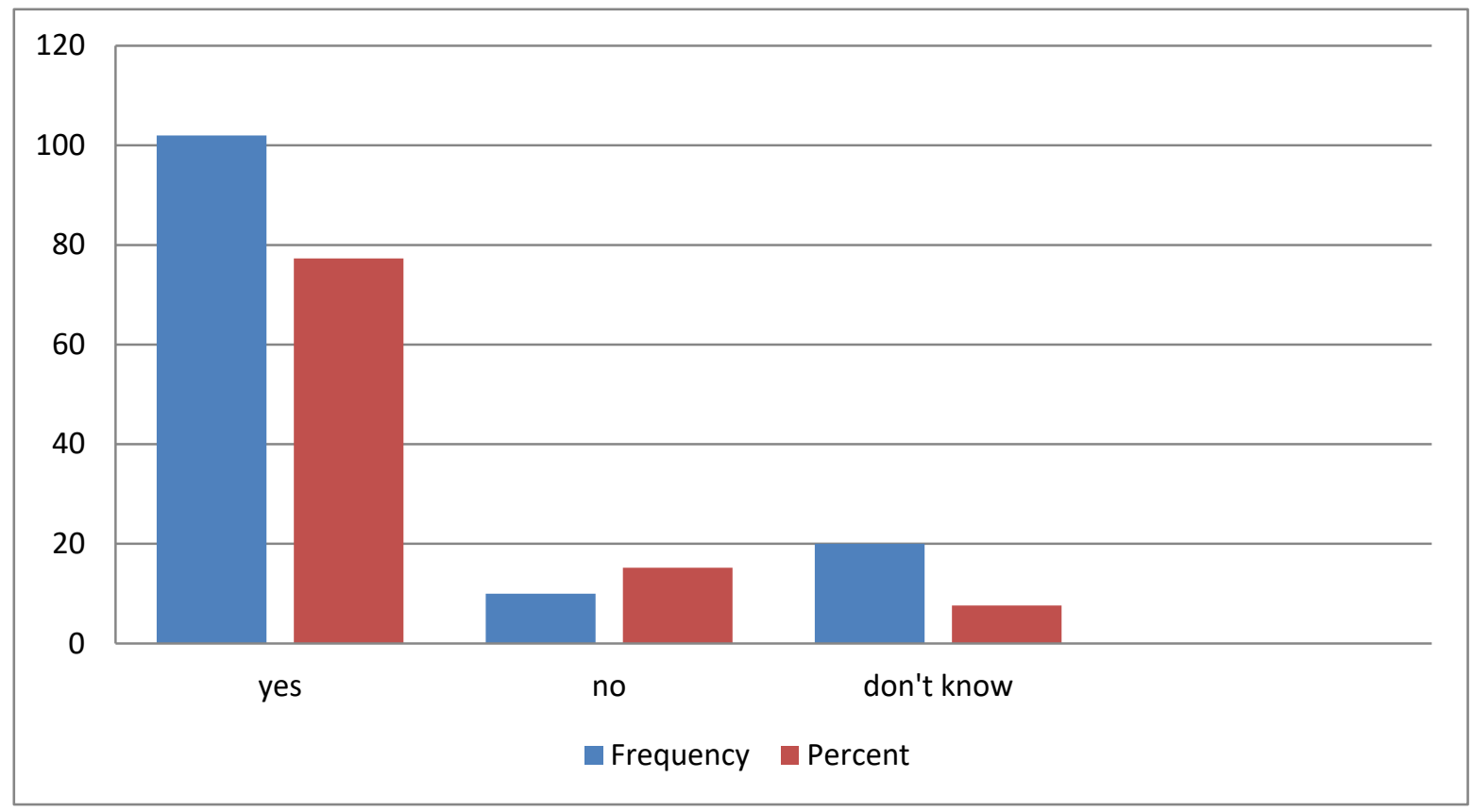

Figure 3. Survey on SMEs regulatory burden in case of reporting requirement

Source: survey result, 2017

As showed in the above Figure 3. Small and medium enterprise survey respondents on regulatory burden in case of reporting requirement about $15.2 \%$ of respondents agreed as there is no burden in terms of cost and time to comply with regulation as a result of reporting requirement, whereas about $77.3 \%$ of respondents believe that it causes high burden in terms of cost and time to comply with regulation and about $7.6 \%$ of respondents responds respond as they don't know. 


\section{Macrothink}

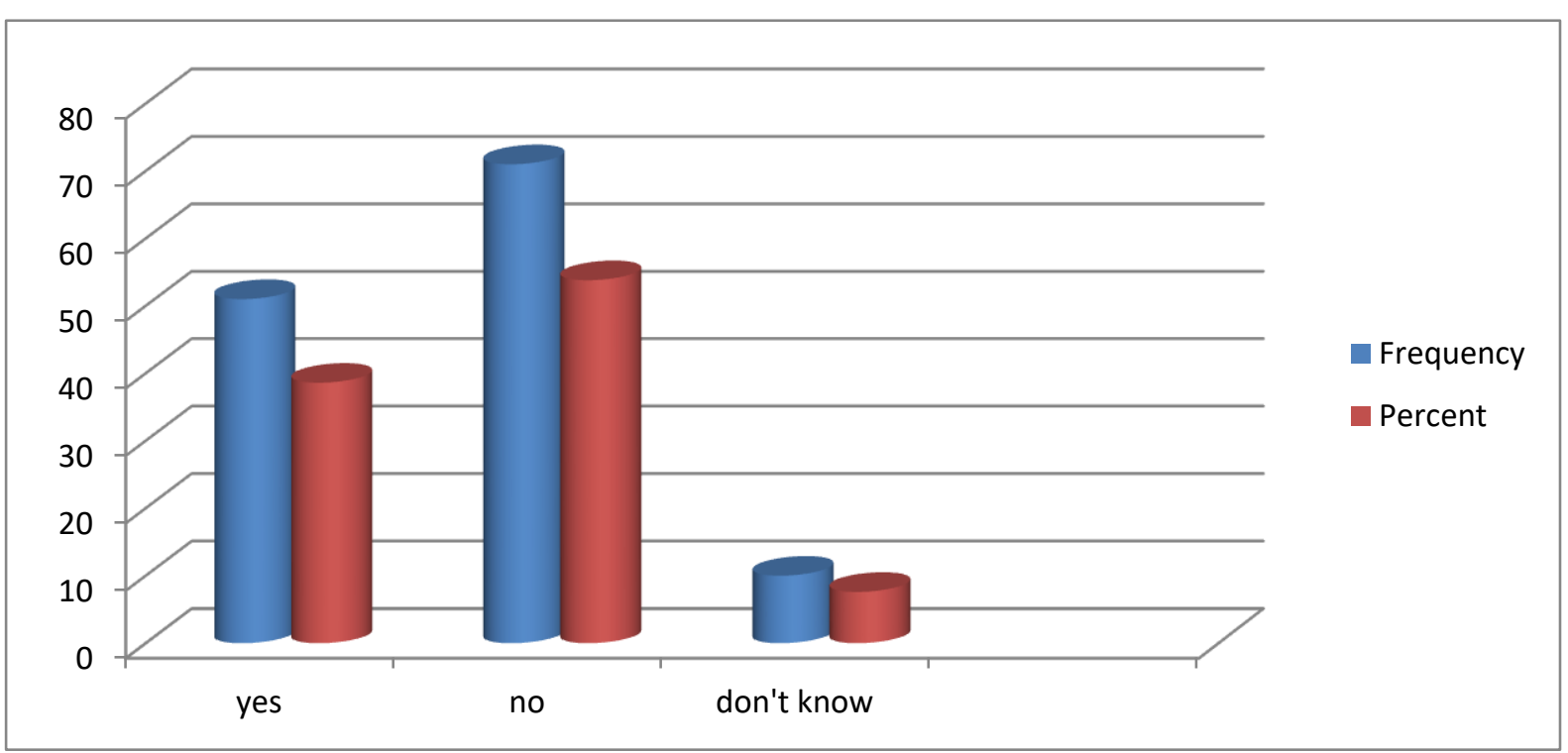

Figure 4. Timing and arrangement of payment as challenges of SMEs business.

Source: survey result, 2017

Regarding timing and arrangement of payment as a challenges for small and medium enterprises businesses about $53.8 \%$ of respondents did not perceived the statements and $38.6 \%$ of respondents agreed with timing and arrangement of payment has not challenge for their business and followed by $7.6 \%$ of respond that do not have no idea on statement.

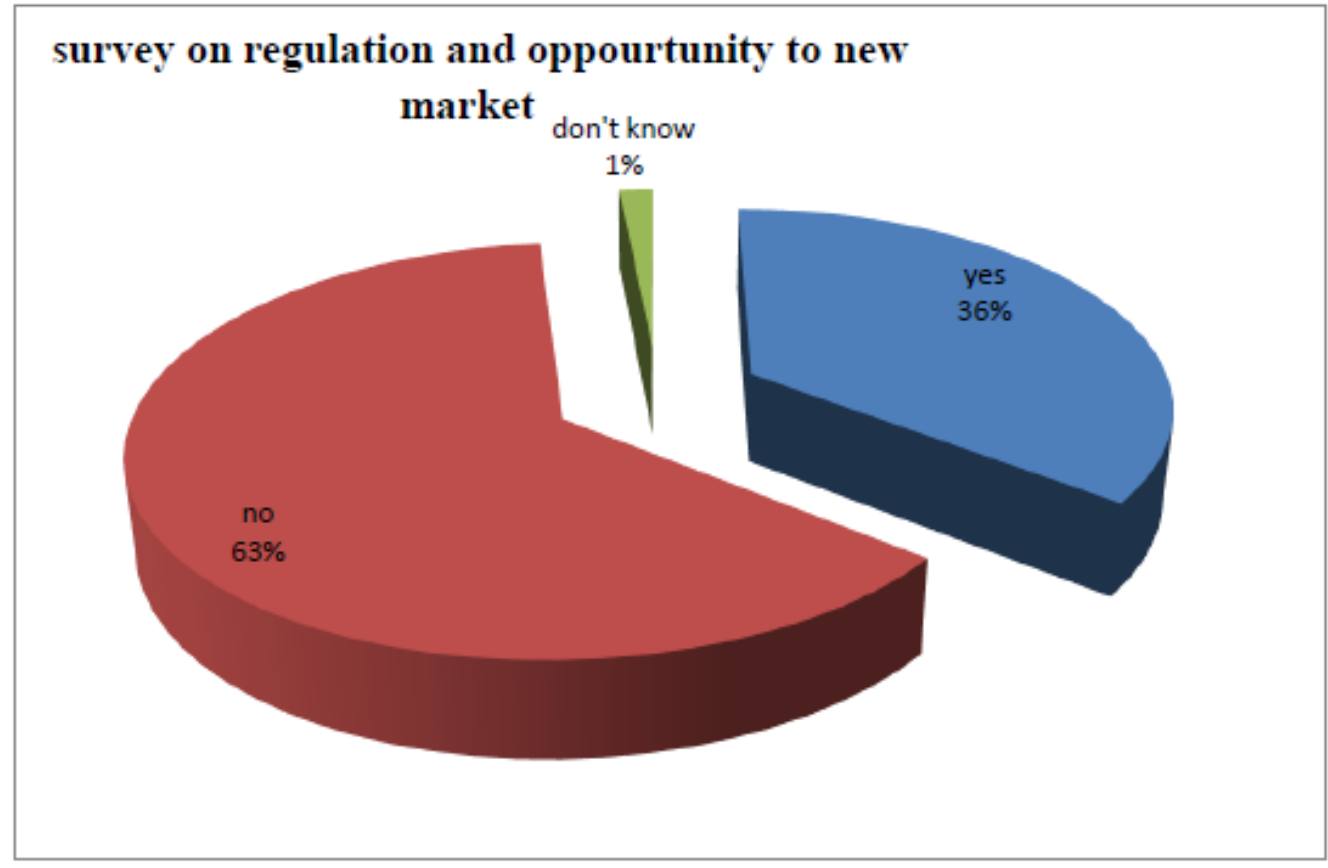

Figure 5. Survey of regulation on opportunity to new market

Source: survey result, 2017 
As it's presented in the above Figure 5 about $62.9 \%$ of respondents stated that regulation did not provide opportunity to inter in to new market and $35 \%$ of respondents respond a regulation provide opportunity to enter in to new market and $1.5 \%$ of respondents have no idea on statements.

\section{Conclusions and Recommendation}

Among the given challenges business regulatory burden was ranked as the first and followed by access to finance it implies that regulatory burden is perceived as an obstacle for the business performance. The next finding is concerned with different areas of regulation (employment, environment and Tax regulation) tax related issues imposed as a major burden on SMEs business performance. The reason that makes each areas of regulation burden for businesses is a factor of different aspects of regulations. With regard to this the study identified that regulations are obstacles because of its complexity and inappropriate inspections. At the same manner frequency of reporting is one part of regulatory requirements considered as a burden by majority of the sectors registered for VAT.

Level of compliance of SMEs with regulation was one of the issues raised under the survey instruments to know their opinion and the findings was majority of respondents are in the state of medium level compliance. Concerning a measure taken by business providing additional training for employees to comply with regulation was viewed by SMEs positively and contribute its part for minimizing burden from regulation.

Inspections of businesses by regulators are varied in different areas of regulation. i.e tax related areas of regulation inspected in yearly base and contribution of regulation relating with market opportunity with new markets viewed negative by the respondents. Finally, perception of small and medium enterprise businesses owners, managers and employees was responded by majority of respondents as its negative impact.

Policy makers and enterprise should give focuses for regulations not to become a burden for business enterprise success. It means with the side of enterprise there should be ready to with regulation through different mechanism and also with the side of regulators to reduce regulatory burden they should try to implement, Enforce and inspect properly. More over policy makers need to take account of areas where the regulatory burden is significant and gives focus not to add the regulatory burden, unless the benefits clearly outweigh the cost.

Both regulators and SMEs should understand how regulation enables and constraints for the business performance. Failure to understand how regulation affect business performance means that policy intervention is likely to produce unwanted consequences.

Government should undertake an assessment on regulatory burden on small and medium enterprise performance and to reduce the regulatory burden from the existing or newly introduced regulation on SMEs.

Policy makers should need to look through on aspects of regulation i.e. they should try to make regulations simple to understand, less in number to manage and minimize rate of changes of regulation in order to reduce the possible burden in terms of time and effort and 
compliance cost.

During contacts with enterprise as much as possible regulators should be clear, flexible, reduce unnecessary bureaucracy and give respect for enterprise. These all enables enterprise to understand easily and adapt regulatory requirements. Government should commit to continuing to lessen the business to understand why they comply about regulation.

The frequency of reporting brought administrative burden and extra cost as identified in the study therefore to reduce administrative burden and extra compliance cost, policy makers should adopt mechanism to reduce reporting requirement burden.

\section{Reference}

Ahmed, A., Mazhar, M. I., \& Howards, I. (2011). A system Approach for the effective Adoption of rapid prototyping for (SMES). [Online] Available:

https://www.researchgate.net/publication/266586153

Anydike, D. M., Athyde, R., Blackburn, R., Harta, M., Kitching, J., Smallbone, D., \& Wilson, N. (2008). The impact of regulation on small business performance; Report for enterprise directorate of BERR. (Project Report) London, U.K.: Department of Business, Enterprise and Regulatory Reform. pp. 138. [Online] Available: http://eprints.kingston.ac.uk/id/eprint/11954

Aryetey, E., \& Ahene, A. (2008). Changing regulatory environment for small and medium size enterprises and their performance in Ghana. Institutes of statistical, social and economic research, university of Ghana. [Online] Available:

https://www.researchgate.net/publication/23512124

Ayyagari, M., Demirgüç-Kunt, A., \& Beck, T. (2003). Small and medium enterprise across the globe: A New Database. Policy Research Working Papers.

https://doi.org/10.1596/1813-9450-3127

Atkinson, J., Tuohy, S., \& Williams, C. (2008). Annual survey of small business UK. Small Business Service. [Online] Available:

https://www.employment-studies.co.uk/resource/annual-survey-small-businesses-uk-2005

Muchie, M., \& Bekele, E. (2009). Promoting micro, small and medium Enterprises (MSMEs) for sustainable rural Livelihood. Aalborg: Institut for Historie, Internationale Studier og Samfundsforhold, Aalborg Universitet. [Online] Available:

https://vbn.aau.dk/ws/portalfiles/portal/17023673/DIIPER_wp_11.pdf

Brixiova, Z., \& Asaminew, E. (2011). SME Start Ups in Ethiopia: Which Incentives Matter?. http://conference.iza.org/conference_files/worldb2010/brixiova_z6063.pdf

Creswell, W. (2007). Research design qualitative, quantities and mixed methods approaches $3^{\text {rd }}$ edition.

Creswell, W. (2009). Research design qualitative, quantities and mixed methods approaches (3rd edition). Dobbs, M. \& Hamilton, R., (2006). Small business growth: recent evidence and new directions. Department of Management, University of Canterbury, Christchurch, New 
Zealand

Djankov, S., McLiesh, C., \& Ramalho, R. M. (2006). Regulation and growth. The World Bank. https://doi.org/10.2139/ssrn.893321

Enkpenyong, N. (2008) Small and medium enterprise and their characteristics, problems and finance.

Gagel, D. (2008). Business registration and legal issue training module. [Online] Available: www.bds-forum.net/training module

Hudson, J. (2003). Why regulation matter: A small business perspective. [Online] Available: https://ideas.repec.org/h/elg/eechap/3926_10.html

John, A. H. (2007). Qualitative and quantitative research design.

Keter, V. (2004). Small firms red tape, business and transport section accessed march.

Kitching, J. (2006). A burden on business reviewing the evidence base on regulation and small business performance. London, Kingston university research repository accessed.

Leung, P., \& Raar, J. (2008). Accounting services and SME An Australian study.

Matthew, W. M., \& Cowling, M., (2009). Annual business survey (2007/08): institute for Nuno, S., Financing small, medium and micro enterprises in post-conflict situations Microfinance opportunities in the Democratic Republic of the Congo.

Olawale, F., \& Garwe, D. (2010). Obstacles to the growth of new small and medium in South Africa.

OECE, (2002). High-growth Small and medium Enterprise and employment accessed.

Quartey, P. (2001). Regulation, competition and small and medium enterprises in developing countries, University of Manchester.

Regulatory Burden in Thailand, (2004). Findings from the Thailand Investment Climate Assessment (ICA).

Review of the Literature, Kingston university Small business survey, (2006). Annual Report and Resource Accounts.

Ruffing, L. (2006). Development through business linkages, UN conference.

Tambunan, N . D. (2011). Development of Small and Medium Enterprises in a Developing Country: The Indonesian Case, centre for Industry and SME Studies.

The Federal Democratic Republic of Ethiopa (FDRE), (2010). Proclamation No. 686/2010 (6:3 and 4), Commercial Registration and Business Licensing' Federal Negarit Gazet, Addis Ababa Ethiopia.

The Federal Democratic Republic of Ethiopia (FDRE), (2002). Proclamation (No. 286/2002), Income tax proclamation, Federal Negarit Gazet, Addis Ababa Ethiopia. 


\section{Macrothink}

Business and Economic Research

ISSN 2162-4860 2020, Vol. 10, No. 1

The Impact of Regulation on Small Business Performance Report for the Enterprise Directorate of BERR (2008). [Online] Available: http://eprints.kingston.ac.uk/11954/

Yesegat, W. (2009). Value added tax in Ethiopia: A study of operating costs and compliance, $\mathrm{PhD}$ thesis, University of New South Wales. [Online] Available:

www.atax.unsw.edu.au/news/taxmatters/>

\section{Copyright Disclaimer}

Copyright for this article is retained by the author(s), with first publication rights granted to the journal.

This is an open-access article distributed under the terms and conditions of the Creative Commons Attribution license (http://creativecommons.org/licenses/by/3.0/). 